\title{
Variation of Yield and Quality in Early Maturing Rice Cultivars by Transplanting Date in Chungnam Plain Area in Korea
}

\author{
Yeo-Tae Yun ${ }^{1,2}$, Chong-Tae Chung ${ }^{1}$, Yeong-Ju Lee ${ }^{1}$, Han-Jung Na ${ }^{1}$, Jae-Chul Lee ${ }^{1}$, Dong-Hee Lee ${ }^{1}$, Kwang-Won Lee ${ }^{1}$, \\ Ju-Won Kang', Sang-Nag $\mathrm{Ahn}^{2} *$ \\ ${ }^{1}$ Chungnam Agricultural Research and Extension Services, Yesan 340-861, Korea \\ ${ }^{2}$ College of Agri. \& Life Sci., Chungnam National University, Daejeon 305-764, Korea
}

\begin{abstract}
Studies were initiated for two consecutive years to examine the effects of transplanting date on the yield and quality of early maturing rice cultivars and to select rice cultivars capable of adapting to early transplanting in the middle plain area. The experiment was laid out in a split-plot design with 3 replications. The main plots consisted of two transplanting dates viz. early (25th of April) and ordinary (25th of May), with sub-plots containing eight cultivars. For early transplanting the mean temperature at the grain filling stage was lower than for ordinary transplanting, while the rice grain quality traits and palatability values were improved. Early transplanting results in 11 days earlier heading, higher head rice yield and lower milled rice yield than ordinary transplanting. Significant differences among the eight cultivars tested in this study were observed for most traits. Among cultivars, 'Joami' demonstrated the highest palatability. 'Joami' also performed better in head rice ratio and head rice yield than 'Unkwang', which is widely cultivated in the middle plain area. Palatability value (PV) showed significant positive correlations with head rice ratio (HR) and amylose content (AC), and negative correlations with chalky rice ratio (CR) and protein content (PC). Mean temperature (MT) was positively correlated with $\mathrm{CR}$ and $\mathrm{PC}$, and negatively correlated with $\mathrm{HR}$ and AC. The highest positive and negative correlations among the rice quality traits were observed between $\mathrm{HR}$ and $\mathrm{AC}(\mathrm{r}=0.734)$, and $\mathrm{HR}$ and $\mathrm{CR}(\mathrm{r}=-0.944)$, respectively. Based on the research findings, 'Joami' is suitable for early transplanting for cultivation in the Chungnam plain area.
\end{abstract}

Keywords Early maturing rice, Transplanting time, Yield, Quality, High temperature

\section{INTRODUCTION}

Early season cultivation of early maturing rice cultivars in plains area is very attractive for many reasons. Farmers can disperse the farm work in other periods and sell the raw rice at a high price before 'Chuseok', Korean Thanksgiving Day. In addition, Rice Processing Complexes (RPC) efficiently operates utilities and use the newly harvested rice as a good marketing tool to manage existing customers and pioneer a new market. As of 2011, the early transplanting cultivation area containing early maturing cultivars reached 42,000 ha, accounting for $46 \%$ of the total area for early maturing cultivars (Lee et al. 2012). For this reason, RPCs make contracts with farmers to grow early maturing rice cultivars by early season cultivation. However, early maturing rice cultivars which have been bred to grow in mid-mountain and mountainous regions tend to display worse grain appearance and eating quality than late maturing rice cultivars when grown in plains areas, mainly due to the high temperature at the grain filling stage (Choi et al. 1994; Choung et al. 2004).

With improvement of the standard of living, the demand for superior rice grain quality has become a priority issue (Yoshinobu et al. 2007; Hao et al. 2009; Lee et al. 2012). The definition of rice grain quality is complex, involving many components such as appearance, cooking quality and eating quality. Among these properties, consumers often pay more attention to appearance (Guo et al. 2011). Rice grain quality can be affected by genetic and environmental factors, especially temperature at the grain filling stage.

Received November 19, 2014; Revised January 12, 2015; Accepted January 27, 2015; Published March 31, 2015

*Corresponding author Sang-Nag Ahn, ahnsn@cnu.ac.kr, Tel: +82-42-821-5728, Fax: +82-42-822-2631 
High temperature during the grain filling stage causes increase in the occurrence of chalky grain and decrease of the head rice ratio (Lisle et al. 2000; Adoration et al. 1977). The most favorable temperature to produce high quality japonica rice was reported to be about $25^{\circ} \mathrm{C}$ at the filling stage (Jin et al. 2005). For this reason, early maturing rice cultivars grown in plains areas display bad grain appearance and eating quality compared with those grown in midmountain and mountainous regions (Choi et al. 1994; Choung et al. 2004), because they experience higher temperature during the ripening stage. The reason for the decrease in rice quality is that the high temperatures interfere with kernel development and reduce the carbohydrates in the plant during the grain filling stage, leading to a decrease in the head rice ratio as well as the appearance traits $(\mathrm{He} e t$ al. 1990; Morita 2008; Morita and Nakano 2011).

A number of early maturing rice cultivars have been grown in plains areas for early harvest. Rice grain quality was reported to be different among cultivars tested under high temperatures (Nishimura et al. 2000). 'Unkwang', widely grown since 2004 due to its high yield, showed the worst appearance and grain quality among cultivars tested when cultivated in plains areas by early season cultivation (Lee et al. 2008). For these reasons, there is a need to replace Unkwang with other early maturing cultivars with better quality. Although the early maturing cultivars grown in plains areas after late transplanting display similar quality traits compared with medium maturing cultivars (Choi et al. 2005), it is difficult to harvest the rice before 'Chuseok' with late transplanting, and it has been used only for double cropping.
Improving the heat tolerance of rice is one way to solve this problem (Morita 2008), and genetic studies have been carried out to examine heat tolerance for the breeding of heat-tolerant cultivars. In Japan, heat-tolerant rice cultivars such as 'Nikomaru' (Sakai et al. 2010), 'Kumasannochikara' (Fujii et al. 2009), 'Genkitsukushi' (Wada et al. 2010) and 'Akisakari' (Tanoi et al. 2010) were developed. The heattolerant cultivars showed better appearance with lower chalky rice ratio at high temperatures during the ripening stage than other cultivars (Kohei et al. 2009). Early maturing rice cultivars adaptable to plains areas should be tolerant to high temperature during the ripening stage. However, a limited number of studies have investigated the adaptability of early maturing rice cultivars to plains areas, or for tolerance to high temperature in Korea (Choi et al. 2005; Choung et al. 2004; Lee et al. 2008; Lee et al. 2012). The present study was conducted to determine the effects of transplanting date on the yield and quality of early maturing cultivars, and to select the cultivars adaptable to early transplanting in middle plains areas.

\section{MATERIALS AND METHODS}

\section{Plant materials and field trial}

Eight early maturing japonica cultivars were used to evaluate variation in yield and quality traits (Table 1). They were developed between 2000 and 2008, and had close relationships. Three cultivars, 'Goun', 'Joan', and 'Odae 1,' shared 'Jinbu 10' as the crossing parent. Seedlings of eight early maturing commercial rice cultivars were raised

Table 1. List of rice cultivars used in this study.

\begin{tabular}{cccc}
\hline \hline Cultivar & Line designation & Cross combination & Year of development \\
\hline Goun & Jinbu 36 & Jinbu 10/Jinbu 17 & 2004 \\
Joami & Sangju 36 & Sambaeg//Yukara/Tonggae 112 & 2008 \\
Joan & Suweon 478 & Jinmibyeo/Jinbu 10 & 2003 \\
Jokwang & Milyang 213 & Milyang 187/YR21113-B-B & 2007 \\
Junamjosaeng & Milyang 208 & Milyang 165/Koshikari & 2006 \\
Odae 1 & Jinbu 37 37 Ilpumbyeo/Jinbu 10 & 2005 \\
Taebong & Cheolweon 59 59 SR13330-13-3-5/Jinbubyeo & 2000 \\
Unkwang & Unbong 30 & Sobibyeo/Cheolweon 54 & 2004 \\
\hline
\end{tabular}


in greenhouses for 30 days after sowing and then transplanted on the 25th of April and the 25th of May, respectively. A total of 4-5 seedlings were planted per hill, with the spacing of $15 \mathrm{~cm}$ between plants and $30 \mathrm{~cm}$ between rows, in the experimental field of the Chungcheongnam-do Agricultural Research and Extension Services (CNARES) in 2009 and 2010. A split plot design with three replications was employed with the transplanting date as the main plot, and cultivars as the subplots. In the subplots, seedlings of each cultivar were planted in 7 lines, with 32 plants per line. Fertilizer $\left(\mathrm{N}-\mathrm{P}_{2} \mathrm{O}_{5}-\mathrm{K}_{2} \mathrm{O}\right)$ was applied at the rate of $90-45-57$ $\mathrm{kg} / \mathrm{ha}$.

\section{Trait evaluation}

Nine agronomic traits were investigated according to the standard of research and investigation for agronomic traits (RDA 2003): days to heading (DTH; the number of days from sowing to emergence of $50 \%$ of the panicle head); culm length (CL; the distance between the soil surface to the tip of the tallest panicle neck); panicle length (PL; the distance between the panicle neck and panicle tip); panicle number ( $\mathrm{PN}$; the number of productive tillers per hill); spikelets per panicle (SPP; the average number of spikelets counted on all panicles of 3 plants); milled rice yield (YD); ripened grain ratio (the average no. of fully ripened grains counted on 3 plants). Yield of milled rice (YD) was measured and calculated as the average weight of bulked grain harvested from 100 plants per line. The YD was corrected for $15 \%$ grain moisture content.

Each rice sample was harvested when the accumulated mean temperature reached $1,100^{\circ} \mathrm{C}$ after heading. After harvesting, rice grains were air-dried until the moisture content reached $15 \%$, and then dehulled to yield brown rice. Each brown rice sample was milled to $92 \%$ milling yield by a polishing machine (Toyo, Japan), and then the milled samples were stored in a refrigerator $\left(15^{\circ} \mathrm{C}\right)$ to prevent change of quality. Head rice ratio (HR, unbroken and broken translucent grains with at least $3 / 4$ of a whole grain), chalky rice ratio (CR, grains with an opaque, chalky appearance covering at least half of the body of the grain), and the broken and defected rice ratio (damaged and discolored rice) were calculated with an RN-300 automatic rice grader using a sample of 1,000 grains. Protein content (PC) and amylose content (AC) of milled rice was measured with a Grain Analyzer (AN700 Kett, Japan) using 100g milled rice samples. Palatability value (PV) was calculated for 33g samples of milled rice by the Toyo taste meter (MA-90A and 90B, Toyo, Japan), in accordance with the operation manual (TRCM Co., Japan). Meteorological data were collected from the Korean Meteorological Administration homepage (http://www.kma.go.kr), and the mean temperature (MT), diurnal range (DR) and sunshine hours (SH) for 30 days after heading were calculated.

\section{Statistical analysis}

Data were analyzed with year, transplanting date and cultivar as the main, subplot and sub-subplot, respectively, using a split-split plot design. ANOVA indicated that F-values for the effect of main-plot and all interaction terms were not significant, so averages of the data for the two years were used in statistical analysis. The $t$-test, analysis of variance and correlation analysis were performed using SPSS software (Ver. 18.0.0). Phenotypic means of each cultivar were compared using Duncan's multiple range test.

\section{RESULTS}

\section{Meteorological data}

The meteorological data for 30 days after heading, according to transplanting time and cultivar, are shown in Table 2. No differences were observed among cultivars for three components. However, there was a significant difference between the two transplantion times. Early transplanting showed a lower mean temperature and diurnal range, with shorter sunshine hours than ordinary transplanting. Mean air temperatures during the growing season in 2009 and 2010, and the average of five years from 2004 to 2008, are shown in Fig. 1. In July and August, the mean temperature for 2009 was lower than 2010, while the mean temperature in 2010 was higher than the five-year average examined. 


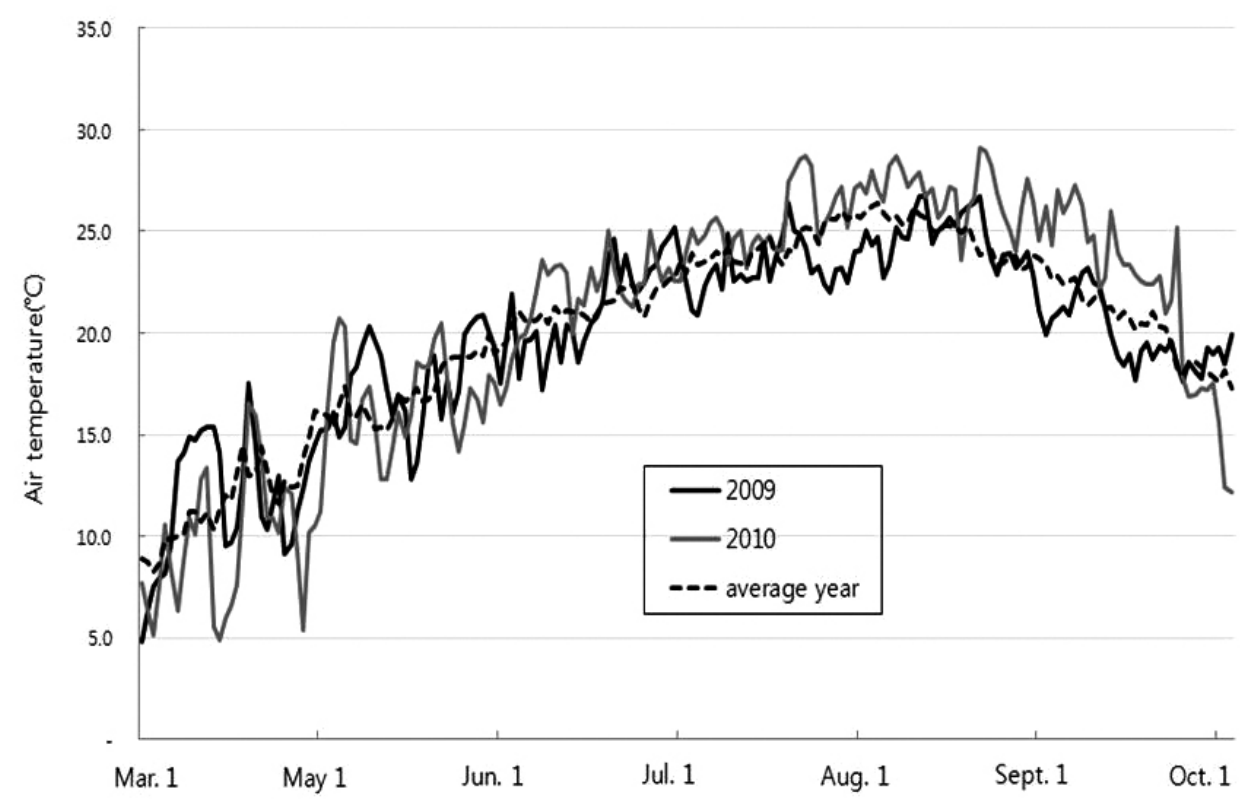

Fig. 1. Mean air temperature during the growing season in 2009 and 2010, and the average of five years from 2004 to 2008. Black, gray, and broken lines indicate air temperature in 2009, 2010, and the average of 5 years, respectively. Data were obtained from the website of the Korean Meteorological Administration (http://www.kma.go.kr).

Table 2. Meteorological data for 30 days after heading, by transplanting time and cultivar.

\begin{tabular}{|c|c|c|c|c|c|}
\hline $\begin{array}{l}\text { Transplanting } \\
\text { time }\end{array}$ & Cultivar & $\begin{array}{c}\text { Heading } \\
\text { date }\end{array}$ & $\begin{array}{c}\text { Mean temperature } \\
\left({ }^{\circ} \mathrm{C}\right)\end{array}$ & $\begin{array}{c}\text { Diurnal range } \\
\left({ }^{\circ} \mathrm{C}\right)\end{array}$ & $\begin{array}{c}\text { Sunshine hour } \\
\text { (hr) }\end{array}$ \\
\hline \multirow{8}{*}{$\begin{array}{c}\text { Early } \\
\text { (April 25) }\end{array}$} & Goun & July 13 & 24.3 & 8.40 & 129.1 \\
\hline & Joami & July 18 & 24.8 & 8.17 & 134.4 \\
\hline & Joan & July 16 & 24.7 & 8.03 & 130.1 \\
\hline & Jokwang & July 21 & 24.9 & 8.50 & 149.3 \\
\hline & Junamjosaeng & July 20 & 24.9 & 8.43 & 148.4 \\
\hline & Odae 1 & July 14 & 24.7 & 8.17 & 130.7 \\
\hline & Taebong & July 14 & 24.5 & 8.30 & 129.3 \\
\hline & Unkwang & July 19 & 24.9 & 8.50 & 138.5 \\
\hline \multirow{8}{*}{$\begin{array}{l}\text { Ordinary } \\
\text { (May 25) }\end{array}$} & Goun & July 25 & 25.0 & 8.50 & 153.2 \\
\hline & Joami & July 29 & 25.2 & 8.57 & 155.9 \\
\hline & Joan & July 26 & 25.1 & 8.63 & 159.8 \\
\hline & Jokwang & July 29 & 24.9 & 8.47 & 150.7 \\
\hline & Junamjosaeng & July 31 & 25.1 & 8.43 & 153.4 \\
\hline & Odae 1 & July 25 & 25.1 & 8.70 & 162.1 \\
\hline & Taebong & July 25 & 25.0 & 8.50 & 154.7 \\
\hline & Unkwang & July 28 & 25.1 & 8.50 & 153.6 \\
\hline \multirow{3}{*}{ Mean } & Early & July 16 & 25.8 & 8.31 & 137.5 \\
\hline & Ordinary & July 27 & 26.1 & 8.54 & 155.4 \\
\hline & Difference $^{z)}$ & - & $-8.179 * *$ & $-6.012 * *$ & $-3.747 * *$ \\
\hline
\end{tabular}

\footnotetext{
z) $* * *$ : Significantly different between two transplanting times at $\mathrm{P}=0.05$ and 0.01 , respectively.
} 


\section{Variation of agronomic traits}

Upon early transplanting, the days to heading was an average of 11 days shorter than ordinary transplanting, with 'Goun' and 'Taebong' being the earliest among the cultivars tested (Table 3). Culm length and panicle length showed significant differences according to the transplanting date. Those in early transplanting were 7.5 and 0.6 $\mathrm{cm}$ shorter, respectively. No differences were observed in the number of panicles and spikelets, and in the grain filling ratios between the two transplanting dates. However, differences among the cultivars were detected for all agronomic traits according to transplanting date. Among the cultivars tested, Unkwang showed the shortest culm and the longest panicle. Long panicles may be associated with large numbers of spikelets and lower grain filling ratios. 'Goun' showed the reverse trend of 'Unkwang,' while 'Joami' had the highest number of panicles among the cultivars.

Grain yield is the most important element in rice production, and is also affected by environmental factors. As shown in Table 4, significant differences were observed in all yields between the two transplanting dates. Milled rice yield was lower for early transplanting than late transplanting. In addition, 'Unkwang' recorded the highest milled rice yield, while 'Goun' was the lowest in both transplanting. Head rice yield was higher for early transplanting, with differences between the transplanting times. When transplanted early, 'Joami' and 'Joan' had the

Table 3. Comparison of agronomic traits and yield components by transplanation time and cultivar.

\begin{tabular}{|c|c|c|c|c|c|c|c|c|}
\hline \multirow{3}{*}{$\begin{array}{l}\text { Transplanting } \\
\text { time (A) }\end{array}$} & \multirow{3}{*}{$\begin{array}{l}\text { Cultivar } \\
\text { (B) }\end{array}$} & \multicolumn{7}{|c|}{ " Trait $^{\mathrm{z})}$} \\
\hline & & \multirow[b]{2}{*}{$\begin{array}{l}\text { Days to } \\
\text { heading }\end{array}$} & \multirow{2}{*}{$\begin{array}{l}\text { Culm } \\
\text { length } \\
(\mathrm{cm})\end{array}$} & \multirow{2}{*}{$\begin{array}{l}\text { Panicle } \\
\text { length } \\
(\mathrm{cm})\end{array}$} & \multirow[b]{2}{*}{$\begin{array}{l}\text { Panicles } \\
\text { /hill }\end{array}$} & \multicolumn{2}{|c|}{ No. spikelets } & \multirow{2}{*}{$\begin{array}{c}\text { Ripened } \\
\text { Grain ratio } \\
(\%)\end{array}$} \\
\hline & & & & & & ea/panicle & $\begin{array}{c}\mathrm{ea} / \mathrm{m}^{2} \\
(\times 1,000)\end{array}$ & \\
\hline \multirow{8}{*}{$\begin{array}{c}\text { Early } \\
\text { (April 25) }\end{array}$} & Goun & $77.6 \mathrm{e}$ & $74 \mathrm{a}$ & $18.1 \mathrm{c}$ & $14.7 \mathrm{bc}$ & $72.7 \mathrm{~d}$ & $25.4 \mathrm{c}$ & $91.3 \mathrm{a}$ \\
\hline & Joami & $82.8 \mathrm{~b}$ & $69 \mathrm{ab}$ & $18.0 \mathrm{c}$ & $19.0 \mathrm{a}$ & $69.2 \mathrm{~d}$ & $31.3 \mathrm{bc}$ & $87.5 \mathrm{ab}$ \\
\hline & Joan & $81.6 \mathrm{bc}$ & $71 \mathrm{ab}$ & $19.0 \mathrm{~b}$ & $14.1 \mathrm{bc}$ & $92.4 \mathrm{~b}$ & $31.0 \mathrm{bc}$ & $88.6 \mathrm{ab}$ \\
\hline & Jokwang & $85.7 \mathrm{~b}$ & $66 \mathrm{~b}$ & $17.9 \mathrm{c}$ & $16.0 \mathrm{~b}$ & $78.9 \mathrm{c}$ & $30.0 \mathrm{bc}$ & $87.9 \mathrm{ab}$ \\
\hline & Junamjosaeng & $85.8 \mathrm{a}$ & $70 \mathrm{ab}$ & $18.0 \mathrm{c}$ & $14.2 \mathrm{bc}$ & $82.7 \mathrm{c}$ & $27.9 \mathrm{c}$ & $91.3 \mathrm{a}$ \\
\hline & Odae 1 & $79.8 \mathrm{~cd}$ & $70 \mathrm{ab}$ & $19.0 \mathrm{~b}$ & $11.5 \mathrm{~d}$ & $97.4 \mathrm{~b}$ & $26.7 \mathrm{c}$ & $91.1 \mathrm{a}$ \\
\hline & Taebong & $78.3 \mathrm{de}$ & $68 \mathrm{ab}$ & $19.6 \mathrm{ab}$ & $14.7 \mathrm{bc}$ & $91.0 \mathrm{~b}$ & $31.9 \mathrm{~b}$ & $85.4 \mathrm{bc}$ \\
\hline & Unkwang & $83.2 \mathrm{~b}$ & $65 \mathrm{~b}$ & $19.8 \mathrm{a}$ & $12.6 \mathrm{~cd}$ & $112.7 \mathrm{a}$ & $33.8 \mathrm{a}$ & $82.3 \mathrm{c}$ \\
\hline \multirow{8}{*}{$\begin{array}{l}\text { Ordinary } \\
\text { (May 25) }\end{array}$} & Goun & $60.5 \mathrm{~g}$ & $81 \mathrm{a}$ & $18.4 \mathrm{c}$ & $14.6 \mathrm{bc}$ & $85.3 \mathrm{c}$ & $29.6 \mathrm{c}$ & $90.9 \mathrm{ab}$ \\
\hline & Joami & $64.8 \mathrm{c}$ & $77 \mathrm{~b}$ & $18.3 \mathrm{c}$ & $18.4 \mathrm{a}$ & $72.8 \mathrm{~d}$ & $31.9 \mathrm{c}$ & $87.0 \mathrm{~cd}$ \\
\hline & Joan & $62.7 \mathrm{e}$ & $81 \mathrm{a}$ & $20.5 \mathrm{a}$ & $14.3 \mathrm{c}$ & $105.6 \mathrm{a}$ & 35.9 a & $84.6 \mathrm{~d}$ \\
\hline & Jokwang & $69.7 \mathrm{a}$ & $72 \mathrm{c}$ & $18.4 \mathrm{c}$ & $16.3 \mathrm{~b}$ & $83.2 \mathrm{c}$ & $32.3 \mathrm{bc}$ & $91.8 \mathrm{a}$ \\
\hline & Junamjosaeng & $66.8 \mathrm{~b}$ & $76 \mathrm{~b}$ & $18.2 \mathrm{c}$ & $14.6 \mathrm{bc}$ & $86.2 \mathrm{c}$ & $30.0 \mathrm{c}$ & $89.5 \mathrm{abc}$ \\
\hline & Odae 1 & $61.5 \mathrm{f}$ & $80 \mathrm{a}$ & $19.4 \mathrm{~b}$ & $13.0 \mathrm{c}$ & $97.6 \mathrm{~b}$ & $30.2 \mathrm{c}$ & $90.7 \mathrm{ab}$ \\
\hline & Taebong & $59.8 \mathrm{~g}$ & $74 \mathrm{c}$ & $20.2 \mathrm{a}$ & $14.3 \mathrm{c}$ & $101.3 \mathrm{ab}$ & $34.5 \mathrm{ab}$ & 88.4 bc \\
\hline & Unkwang & $63.8 \mathrm{~d}$ & $70 \mathrm{~d}$ & $20.3 \mathrm{a}$ & $14.4 \mathrm{bc}$ & $107.5 \mathrm{a}$ & $36.8 \mathrm{a}$ & $78.9 \mathrm{e}$ \\
\hline \multirow{3}{*}{ Mean } & Early & 81.8 & 69.0 & 18.6 & 14.6 & 87.1 & 30.5 & 88.2 \\
\hline & Ordinary & 63.7 & 76.5 & 19.2 & 14.9 & 92.4 & 32.8 & 87.7 \\
\hline & Difference $^{\mathrm{y})}$ & $20.3 * *$ & $-6.5 * *$ & $-2.045^{*}$ & $\mathrm{~ns}$ & ns & $-2.521 *$ & ns \\
\hline Interaction & $\mathrm{A} \times \mathrm{B}$ & $5.481 * *$ & ns & ns & $\mathrm{ns}$ & $5.243 * *$ & $\mathrm{~ns}$ & $\mathrm{~ns}$ \\
\hline
\end{tabular}

${ }^{2)}$ Means with the same letters in a column for each transplanting date are not significantly different at the $5 \%$ level, as determined by Duncan's multiple range test.

y) $*, * *$ : Significantly different between two transplanting times at 0.05 and 0.01 , respectively. 
Table 4. Milled and head rice yield by transplanting date and cultivar.

\begin{tabular}{|c|c|c|c|c|c|}
\hline $\begin{array}{c}\text { Transplanting } \\
\text { time (A) }\end{array}$ & $\begin{array}{l}\text { Cultivar } \\
\text { (B) }\end{array}$ & $\begin{array}{l}\left.\text { Milled rice yield }{ }^{\mathrm{z}}\right) \\
(\mathrm{kg} / 10 \mathrm{a})\end{array}$ & $\begin{array}{l}\text { Yield index of } \\
\text { milled rice }\end{array}$ & $\begin{array}{c}\text { Head rice yield }{ }^{2)} \\
(\mathrm{kg} / 10 \mathrm{a})\end{array}$ & $\begin{array}{l}\text { Yield index of } \\
\text { head rice }\end{array}$ \\
\hline \multirow{8}{*}{$\begin{array}{c}\text { Early } \\
\text { (April 25) }\end{array}$} & Goun & $461 \mathrm{~d}$ & 81 & $386 \mathrm{~d}$ & 93 \\
\hline & Joami & $529 \mathrm{~b}$ & 93 & $451 \mathrm{ab}$ & 108 \\
\hline & Joan & $525 \mathrm{~b}$ & 92 & $470 \mathrm{a}$ & 113 \\
\hline & Jokwang & $509 \mathrm{cb}$ & 89 & $413 \mathrm{c}$ & 99 \\
\hline & Junamjosaeng & $501 \mathrm{cb}$ & 88 & $410 \mathrm{c}$ & 99 \\
\hline & Odae 1 & $480 \mathrm{c}$ & 84 & $411 \mathrm{c}$ & 99 \\
\hline & Taebong & $506 \mathrm{cb}$ & 89 & $432 \mathrm{bc}$ & 104 \\
\hline & Unkwang & 569 a & 100 & $416 \mathrm{c}$ & 100 \\
\hline \multirow{8}{*}{$\begin{array}{c}\text { Ordinary } \\
\text { (May 25) }\end{array}$} & Goun & $488 \mathrm{e}$ & 83 & $388 \mathrm{~d}$ & 97 \\
\hline & Joami & $546 \mathrm{~b}$ & 93 & $429 \mathrm{ab}$ & 107 \\
\hline & Joan & $537 \mathrm{bc}$ & 91 & $399 \mathrm{~cd}$ & 100 \\
\hline & Jokwang & $528 \mathrm{c}$ & 89 & $441 \mathrm{a}$ & 110 \\
\hline & Junamjosaeng & $506 \mathrm{~d}$ & 86 & $414 \mathrm{bc}$ & 103 \\
\hline & Odae 1 & $509 \mathrm{~d}$ & 86 & $396 \mathrm{~cd}$ & 99 \\
\hline & Taebong & $540 \mathrm{bc}$ & 92 & $410 \mathrm{bcd}$ & 102 \\
\hline & Unkwang & $590 \mathrm{a}$ & 100 & $401 \mathrm{~cd}$ & 100 \\
\hline \multirow{3}{*}{ Mean } & Early & 509 & 89.5 & 423 & 101.9 \\
\hline & Ordinary & 530 & 90.0 & 409 & 102.3 \\
\hline & Difference $e^{\mathrm{y}}$ & $-2.173 *$ & - & $2.475^{*}$ & - \\
\hline Interaction & $\mathrm{A} \times \mathrm{B}$ & ns & - & $4.655^{* *}$ & - \\
\hline
\end{tabular}

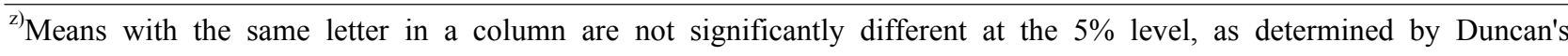
multiple range test.

y)*, ** : Significantly different between two transplanting times at 0.05 and 0.01 , respectively.

highest head rice yield, while 'Joami' and 'Jokwang' were the highest for the ordinary transplanting time.

\section{Rice appearance traits}

Rice appearance quality is the most important trait in rice production because it influences customer selection when buying rice. For example, rice with high head and low defects is considered to be high quality, and the appearance quality can easily be compared by customers in a short time without any equipment. For this reason, RPCs try to improve the head rice ratio, with the penalty of low milling yield. The results of rice appearance traits according to transplanting times and cultivars are summarized in Table 5. Most of the traits showed significant interaction between transplanting time and cultivar. Head rice ratio showed significant differences between the two times, with the early transplanted rice displayed 5.8\% more head. 'Joan' showed the highest head rice ratio in early transplanting, while 'Jokwang' was the highest for the ordinary time. 'Unkwang' had the highest proportion of chalky rice among the eight rice cultivars for both transplanting dates.

\section{Physicochemical traits and palatability value}

Protein and amylose content of the rice also showed significant differences between the transplanting dates and among the cultivars examined herein (Table 6). The protein content was lower for early transplanting by $0.35 \%$. The highest protein content was observed in 'Joan' with the lowest in 'Junamjosaeng' for both dates. Amylose content ranged from $18.06 \%$ (Unkwang) to $18.61 \%$ (Goun). As for 
Table 5. Rice appearance traits by transplanting time and cultivar.

\begin{tabular}{|c|c|c|c|c|c|}
\hline \multirow{2}{*}{$\begin{array}{l}\text { Transplanting } \\
\text { Time (A) }\end{array}$} & \multirow{2}{*}{$\begin{array}{l}\text { Cultivar } \\
\text { (B) }\end{array}$} & \multicolumn{4}{|c|}{ Rice Appearance Traits $^{\mathrm{z}}$} \\
\hline & & Head $(\%)$ & Chalky (\%) & Broken $(\%)$ & Defect $(\%)$ \\
\hline \multirow{8}{*}{$\begin{array}{c}\text { Early } \\
\text { (April 25) }\end{array}$} & Goun & $84.2 \mathrm{bc}$ & $4.6 \mathrm{f}$ & $9.4 \mathrm{a}$ & 1.8 \\
\hline & Joami & $85.4 \mathrm{~b}$ & $9.5 \mathrm{bcd}$ & $3.7 \mathrm{~cd}$ & 1.4 \\
\hline & Joan & $89.8 \mathrm{a}$ & 5.7 ef & $3.1 \mathrm{~d}$ & 1.4 \\
\hline & Jokwang & $80.6 \mathrm{c}$ & $10.1 \mathrm{bc}$ & $7.5 \mathrm{ab}$ & 1.8 \\
\hline & Junamjosaeng & $82.3 \mathrm{bc}$ & $12.2 \mathrm{~b}$ & $4.6 \mathrm{~cd}$ & 0.9 \\
\hline & Odae 1 & $85.6 \mathrm{~b}$ & 8.3 cde & $4.3 \mathrm{~cd}$ & 1.8 \\
\hline & Taebong & $85.5 \mathrm{~b}$ & $6.8 \mathrm{def}$ & $4.9 \mathrm{bcd}$ & 2.8 \\
\hline & Unkwang & $73.1 \mathrm{~d}$ & $19.5 \mathrm{a}$ & $5.7 \mathrm{c}$ & 1.7 \\
\hline \multirow{8}{*}{$\begin{array}{l}\text { Ordinary } \\
\text { (May 25) }\end{array}$} & Goun & $79.3 \mathrm{bc}$ & $12.5 \mathrm{~d}$ & $4.3 \mathrm{ab}$ & $3.9 \mathrm{~b}$ \\
\hline & Joami & $78.5 \mathrm{bc}$ & $17.5 \mathrm{c}$ & $2.7 \mathrm{c}$ & $1.3 \mathrm{c}$ \\
\hline & Joan & $74.4 \mathrm{~d}$ & $21.3 \mathrm{~b}$ & $2.8 \mathrm{bc}$ & $1.5 \mathrm{c}$ \\
\hline & Jokwang & 83.6 a & $12.4 \mathrm{~d}$ & $2.4 \mathrm{c}$ & $1.6 \mathrm{c}$ \\
\hline & Junamjosaeng & $82.1 \mathrm{ab}$ & $13.4 \mathrm{~d}$ & $3.3 \mathrm{bc}$ & $1.2 \mathrm{c}$ \\
\hline & Odae 1 & $78.0 \mathrm{~cd}$ & $16.7 \mathrm{c}$ & $3.9 \mathrm{~b}$ & $1.4 \mathrm{c}$ \\
\hline & Taebong & $76.0 \mathrm{~cd}$ & $15.5 \mathrm{~cd}$ & $3.7 \mathrm{bc}$ & $4.8 \mathrm{a}$ \\
\hline & Unkwang & $68.1 \mathrm{e}$ & $25.4 \mathrm{a}$ & $5.5 \mathrm{a}$ & 1.0 \\
\hline \multirow{3}{*}{ Mean } & Early & 83.3 & 9.6 & 5.4 & 1.7 \\
\hline & Ordinary & 77.5 & 16.8 & 3.6 & 2.1 \\
\hline & Difference $^{\mathrm{y})}$ & $4.026^{* *}$ & $5.302 * *$ & $3.495^{* *}$ & $\mathrm{~ns}$ \\
\hline Interaction & $A \times B$ & $10.209 * *$ & $9.172 * *$ & $14.107 * *$ & $\mathrm{~ns}$ \\
\hline
\end{tabular}

${ }^{2)}$ Means with the same letter in a column are not significantly different at the $5 \%$ level, as determined by Duncan's multiple range test.

y)*,**: Significantly different between two transplanting times at 0.05 and 0.01 , respectively.

the palatability value, 'Joami' recorded the highest score among the eight cultivars, while 'Unkwang' was the lowest for both transplanting times.

Correlation analysis showed that all traits were significantly correlated with each other (Table 7). PV was positively correlated with $\mathrm{HR}, \mathrm{AC}, \mathrm{DR}$ and $\mathrm{SH}$, but negatively correlated with CR, PC and MT. In addition, MT was positively correlated with $\mathrm{CR}$ and $\mathrm{PC}$, but negatively correlated with $\mathrm{HR}$ and AC. The highest positive and negative correlations observed among rice the quality traits were between $\mathrm{HR}$ and $\mathrm{AC}\left(\mathrm{r}=0.734^{* *}\right)$, and HR and CR $\left(r=-0.944^{* *}\right)$, respectively. These results suggested that the rice quality traits are dependent on each other, and are affected by environmental factors.

\section{DISCUSSION}

Nowadays, early maturing rice cultivars suitable for growth in mid-mountain and mountainous areas are being cultivated in plains areas to sell new crop rice before 'Chuseok', the Korean Thanksgiving Day. The quality of rice grain deteriorates when early maturing rice cultivars are cultivated in plains areas due to the high temperature during the grain filling stage. Yun and Lee (2001) reported that the optimum temperature for the grain filling stage which leads to the production of high quality japonica rice ranged from $21^{\circ} \mathrm{C}$ to $23^{\circ} \mathrm{C}$. The mean temperatures of all rice cultivars tested in this study were over $24.0^{\circ} \mathrm{C}$, leading to a high ratio of chalky rice, while 'Unkwang' was the highest. Chalky rice is easily broken during milling, and has less stickiness than head rice when cooked, which 
Table 6. Physicochemical traits and Palatability value by transplanting date and cultivar.

\begin{tabular}{ccccc}
\hline \hline Transplanting & Cultivar & \multicolumn{3}{c}{ Traits } \\
date (A) & (B) & Protein $(\%)$ & Amylose $(\%)$ & Palatability value \\
\cline { 2 - 4 } & Goun & $6.62 \mathrm{a}$ & $18.61 \mathrm{a}$ & $64.7 \mathrm{~d}$ \\
Joami & $6.27 \mathrm{ab}$ & $18.43 \mathrm{~cd}$ & $74.1 \mathrm{a}$ \\
Early & Joan & $6.52 \mathrm{a}$ & $18.61 \mathrm{a}$ & $68.9 \mathrm{bc}$ \\
(April 25) & Jokwang & $5.91 \mathrm{bc}$ & $18.45 \mathrm{bcd}$ & $65.6 \mathrm{~cd}$ \\
& Junamjosaeng & $5.76 \mathrm{c}$ & $18.56 \mathrm{abc}$ & $69.8 \mathrm{~b}$ \\
& Odae-1 & $6.74 \mathrm{a}$ & $18.58 \mathrm{ab}$ & $67.1 \mathrm{bcd}$ \\
& Taebong & $6.70 \mathrm{a}$ & $18.57 \mathrm{abc}$ & $63.8 \mathrm{~d}$ \\
& Unkwang & $5.93 \mathrm{bc}$ & $18.35 \mathrm{~d}$ & $63.5 \mathrm{~d}$ \\
\hline & Goun & $6.53 \mathrm{~cd}$ & $18.60 \mathrm{a}$ & $65.5 \mathrm{bc}$ \\
Ordinary & Joami & $6.62 \mathrm{c}$ & $18.40 \mathrm{~b}$ & $70.0 \mathrm{a}$ \\
(May 25) & Joan & $7.20 \mathrm{a}$ & $18.35 \mathrm{~b}$ & $63.1 \mathrm{~d}$ \\
& Jokwang & $6.28 \mathrm{e}$ & $18.48 \mathrm{ab}$ & $65.1 \mathrm{c}$ \\
& Junamjosaeng & $6.33 \mathrm{de}$ & $18.43 \mathrm{~b}$ & $66.8 \mathrm{~b}$ \\
& Odae-1 & $7.04 \mathrm{ab}$ & $18.41 \mathrm{~b}$ & $67.1 \mathrm{~b}$ \\
& Taebong & $6.93 \mathrm{~b}$ & $18.46 \mathrm{~b}$ & $62.3 \mathrm{~d}$ \\
\hline Interaction & Unkwang & $6.37 \mathrm{de}$ & $18.06 \mathrm{c}$ & $60.5 \mathrm{e}$ \\
\hline
\end{tabular}

${ }^{2)}$ Means with the same letter in a column are not significantly different at the $5 \%$ level, as determined by Duncan's multiple range test.

y)*,**: Significantly different between two transplanting times at 0.05 and 0.01 , respectively.

Table 7. Correlation coefficients among rice quality traits and environmental factors.

\begin{tabular}{cccccccc}
\hline \hline Trait & HR & CR & PC & AC & PV & MT & DR \\
\hline CR & $-0.94^{* *}$ & & & & & & \\
PC & $-0.35^{* *}$ & $0.40^{* *}$ & & & & & \\
AC & $0.73^{* *}$ & $-0.78^{* *}$ & $-0.39^{* *}$ & & & & \\
PV & $0.56^{* *}$ & $-0.56^{* *}$ & $-0.38^{* *}$ & $0.43^{* *}$ & & & \\
MT & $-0.65^{* *}$ & $0.72^{* *}$ & $0.51^{* *}$ & $-0.77^{* *}$ & $-0.37^{* *}$ & & \\
DR & $0.58^{* *}$ & $-0.59^{* *}$ & $-0.34^{* *}$ & $0.46^{* *}$ & $0.25^{*}$ & $-0.76^{* *}$ & \\
SH & $0.48^{* *}$ & $-0.46^{* *}$ & $-0.31^{* *}$ & $0.43^{* *}$ & $0.24^{*}$ & $-0.67^{* *}$ & $0.94^{* *}$ \\
\hline
\end{tabular}

decreases the palatability. The increase in the ratio of chalky rice might be due to interference with kernel development and reduction in carbohydrates in the plant at the grain filling stage due to the high temperature (Nagata et al. 2004). In addition, high temperature at the grain filling stage influences the physiochemical properties, such as protein and amylose content (Jin et al. 2005; Aboubacar et al. 2006). Several QTL studies reported the colocalization of QTL for heading date and grain quality (Li et al. 2011; Takeuchi et al. 2007, 2008). Nishimura et al. (1985) reported that heading date affected the chemical components such as ADV, and the amylose and protein content, which 
could affect the eating quality. These results imply a causal relationship between heading date and grain quality, because the heading date might determine the timing of the grain filling stage of each cultivar, which is in turn associated with the grain quality traits. In this study, the mean temperature at grain filling stage was positively correlated with PC, but negatively correlated with amylose content. Jin et al. (2005) evaluated the influence of temperature at the filling stage on the activities of key enzymes related to grain starch synthesis to gain an understanding of how temperature influences the biochemical characteristics, and demonstrated that starch synthesis is dependent on temperature. The activity of SBE (starch branching enzyme) was especially sensitive to temperature, reaching a maximum at $25^{\circ} \mathrm{C}$, after which the activity decreased with further rise in temperature. In general, protein content was reported to be negatively correlated with eating quality (Juliano et al. 1965; Ishima et al. 1974), as rice with higher protein content displayed lower adhesiveness and water uptake ratio than that with low protein content, which was also associated with a decrease in the glossiness, taste and stickiness of cooked rice (Yoshinobu et al. 2007; Yanase et al. 1984). The results obtained in the present study also support these observations. Mean temperature during the grain filling stage (MT) for early transplanting was lower than for ordinary transplanting, which may lead to better rice grain quality. MT was negatively correlated with HR and PV, but positively correlated with $\mathrm{CR}$, suggesting that MT clearly affected the rice quality. In addition, early transplanting decreased the number of days to heading by 11 days compared to the ordinary transplanting time, and increased the head rice yield, although the milled rice yield decreased by an average of $21 \mathrm{~kg} / 10 \mathrm{a}$. These results suggest that early transplanting is more advantageous for the production of high quality rice in the middle plains area. Among the 8 rice cultivars tested in this study, 'Unkwang' showed the highest yield, but the lowest values for the rice quality traits, including HR, AC and PV. This is likely due to the fact that the rice quality traits were highly correlated with each other.

In conclusion, early maturing cultivars in the middle plains areas had less desirable grain quality at the ordinary transplanting time than at early transplanting, mainly due to high temperatures during the grain filling stage. Varietal differences were observed among the eight cultivars, depending on the transplanting times. Although 'Joan' had the highest head rice yield for early transplanting, 'Joami' showed the highest palatability value during both times. 'Joami' also performed better in head rice ratio, head rice yield and palatability values than 'Unkwang'. Based on the research findings, 'Joami' might be most suitable for early transplanting cultivation in middle plains areas.

\section{ACKNOWLEDGEMENTS}

This work was supported by the Next-Generation Biogreen 21 Program (Plant Molecular Breeding Center No. PJ008136), Rural Development Administration, Republic of Korea.

\section{REFERENCES}

Aboubacar A, Moldenhauer K, McClung AM, Beighley DH, Hamaker BR. 2006. Effect of growth location in the United States on amylose content, amylopectin fine structure, and thermal properties of starches of long grain rice cultivars. Cereal Chem. 83: 93-98.

Adoration PR, Hara T, Julino BO, Yoshida S. 1977. Effect of temperature during ripening on grain quality of rice. Soil Sci. Plant Nutr. 23(I): 109-112.

Choi HC, Chi JH, Lee CS, Kim YB, Cho SY. 1994. Varietal and locational variation of grain quality components of rice produced in hilly and high altitude areas in Korea. Korean J. Crop Sci. 39(1): 27-37.

Choi WY, Nam JK, Kim SS, Lee JH, Kim JH, Park HK, Back NH, Choi MG, Kim CK, Jung KY. 2005. Optimum transplanting date for production quality rice in Honam plain area. Korean J. Crop Sci. 50(6): 435-441.

Choung JI, Kim KY, Choi YH, Ko JC, Oh MK, Hong HC, Lee SY, Lee MC. 2004. Analysis of chemical and eating quality character of the early rice variety at cultured in the southern plain area. Korean J. Intl. Agri. 16(4): 345-349.

Fujii Y, Mitsukawa M, Sakanashi J, Ueno I, Izumi K, Hatakeyama S, Araki S, Kurata K, Tanaka M. 2009. 
Breeding and characters of a new cultivar 'Kumasannochikara' with resistance to high-temperature during ripening period. Res. Bull. Kumamoto Pref. Agric. Res. Cent. 16: $1-10$.

Guo T, Liu XL, Wan X, Weng J, Liu S, Liu X, Chen M, Li J, Su N, Wu F, Cheng Z, Guo Z, Guo X, Lei C, Wang J, Jiang L, Wan J. 2011. Identification of a stable quantitative trait locus for percentage grains with white chalkiness in rice (Oryza sativa L.). J. Intergr. Plant Biol. 53(8): 598-607.

Hao W, Zhu MZ, Gao JP, Sun SY, Lin HX. 2009. Identification of quantitative trait loci for rice quality in a population of chromosome segment substitution lines. J. Integr. Plant Biol. 51(5): 500-512.

He GC, Kogure K, Suziki H. 1990. Development of endosperm and synthesis of starch in rice grain III Starch property as affected by the temperature during grain development. Japan. J. Crop Sci. 59: 340-345.

Ishima T, Taira H, Taira H, Mikoshiba K. 1974. Effect of nitrogenous fertilizer application and protein content in milled rice on olganoleptic quality of cooked rice. Report of National Food Res. Inst. 29: 9-15

Juliano BO, Onate LU, Mundo AM. 1965. Relations of starch composition, protein content and gelatinization temperature to the cooking and eating quality of milled rice. Food Technol. 19(12): 1006-1011.

Jin ZX, Qian CR, Yang J, Liu HY, Jin XY. 2005. Effect of temperature at grain filling stage on activities of key enzymes related to starch synthesis and grain quality of rice. Rice Sci. 12(4): 261-266.

Kohei T, Ryoki O, Masayuki M, Yushi I, Takashi Y, Mari II. 2009. Changes in NMR relaxation of rice grains, kernel quality and physicochemical properties in response to a high temperature after flowering in heat-tolerant and heat-sensitive rice cultivars. Plant Prod. Sci. 12(2): 185192.

Lee JH, Cho JH, Kim SY, Lee JY, Kim CS, Yeo US, Song YC, Shon YB, Oh MK, Kang HW, Nam MH. 2012. Correlation analysis between head rice ratio and agronomic traits in RILs for developing a promising rice cultivar adaptable to the early-transplanting cultivation. Korean J. Crop Sci. 57(1): $1-6$

Lee JH, Park DS, Kwak DY, Yeo US, Song YC, Kim CS, Jeon MG, Oh BG, Shin MS, Kim JK. 2008. Yield and grain quality of early maturing rice cultivars as affected by early transplanting in Yeongnam plain area. Korean J. Crop Sci.
53(3): 326-332.

Li J, Zhang W, Wu H, Gou T, Liu X, Wan X, Jin J, Hanh T, Thao N, Chen N, Liu S, Chen L, Liu X, Wang J, Zhai H, Wan J. 2011. Fine mapping of stable QTLs related to eating quality in rice (Oryza sativa L.) by CSSLs harboring small target chromosome segments. Breeding Sci. 61: 338-346.

Lisle AJ, Martin M, Fitzgerald MA. 2000. Chalky and translucent rice grains differ in starch composition and structure and cooking properties. Cereal Chem. 77(5): 627-632.

Morita S. 2008. Prospect for developing measures to prevent high-temperature damage to rice grain ripening. Japan. J. Crop Sci. 77: 1-12.

Morita S, Nakano H. 2011. Nonstructural carbohydrate content in the stem at full heading contributes to high performance of ripening in heat-tolerant rice cultivar Nikomaru. Crop Sci. 51: 818-828.

Nagata K, Takita T, Yoshinaga S, Terashima K, Fukuda A. 2004. Effect of air temperature during the early grain filling stage on grain fissuring in rice. Japan. J. Crop Sci. 73(3): 336-342

Nishimura M, Kaji R, Ogawa T. 2000. Varietal difference in the occurrence of coarse grain due to the high temperature stress given during the ripening period of rice plant. Breeding Res. 2(1): 17-22.

Nishimura M, Yamauchi F, Ohuchi K, Hamamura K. 1985. Evaluation of the eating quality of recent rice varieties and lines in Hokkaido- The relation between organoleptic and physicochemical qualities of milled rice harvested in an extremely col year and a very hot year during the summer. Res. Bull. Hokkaido Natl. Agric. Exp. Stn. 144: 77-89.

Rural Development Administration. 2003. Standard of research and investigation for agronomic traits.

Sakai M, Okamoto M, Tamura K, Kaji R, Mizobuchi R, Hirabayashi H, Yagi T, Nishimura M, Fukaura S. 2010. 'Nikomaru', A high-yielding rice variety with superior eating quality and grain appearance under high temperature during ripening. Bull. NARO Kyushu Okinawa Agri. Res. Centre 54: 43-61.

Takeuchi Y, Nonoue Y, Ebitani T, Suzuki K, Aoki N, Sato H, Ideta $\mathrm{O}$, Hirabayashi $\mathrm{H}$, Hirayama M, Ohta H et al. 2007. QTL detection for eating quality including glossiness, stickiness, taste and hardness of cooked rice. Breeding Sci. 57: 231-242. 
Takeuchi Y, Hori K, Suzuki K, Nonoue Y, Takemoto-Kuno Y, Maeda H, Sato H, Hirabatashi H, Ohta H, Ishii T et al. 2008. Major QTLs for eating quality of an elite Japanese rice cultivar, Koshikari, on the short arm of chromosome 3. Breeding Sci. 58: 437-445.

Tanoi M, Tomita K, Kobayashi A, Hayashi T. 2010. Heat tolerance and grain quality of a new rice cultivar 'Akisakari'. Hokuriku Crop Su. 45: 3-6.

Wada T, Tsubone M, Inoue T, Ogata T, Hamachi Y, Matsue Y, Oosato FK, Yasunaga T, Kawamura Y, Ishizuka A. 2010. 'Genkitsukushi', a new cultivar with tolerance to high temperature during maturing period and high eating quality. Bull. Fukuoka Agri. Res. Centre 29: 1-9

Yanase H, Ohtsubo K, Hashimoto K, Sato H, Teranishi T.
1984. Correlation between protein contents of brown rice and textural parameters of cooked rice and cooking quality of rice. Report of National Food Res. Inst. 45: 118-122.

Yoshinobu T. Nonoue Y, Ebitani T, Suzuki K, Aoki N, Sato H, Ideta O, Hirabayashi H, Hirabayashi M, Ohta H, Nemoto H, Kato H, Ando I, Ohtsubo K, Yano M, Imbe T. 2007. QTL detection for eating quality including glossiness, stikiness, taste and hardness of cooked rice. Breeding Sci. 57: 231-242.

Yun SH, Lee JT. 2001. Climate change impacts on optimum ripening periods of rice plant and its counter measure in rice cultivation. Korean Journal of Agricultural and Forest Meteorology 3(1): 55-70. 